\title{
Medievalista
}

Online

13 | 2013

Número 13

\section{Política e politheia nos provérbios romenos do século XVIII}

\author{
Laura Badescu
}

\section{(2) OpenEdition}

Journals

\section{Edição electrónica}

URL: http://journals.openedition.org/medievalista/563

DOI: 10.4000/medievalista.563

ISSN: 1646-740X

\section{Editora}

Instituto de Estudos Medievais - FCSH-UNL

\section{Refêrencia eletrónica}

Laura Badescu, «Política e politheia nos provérbios romenos do século XVIII », Medievalista [Online], 13 | 2013, posto online no dia 19 fevereiro 2014, consultado no dia 21 abril 2019. URL : http:// journals.openedition.org/medievalista/563; DOI : 10.4000/medievalista.563

(C) IEM 
Título: Política e politheia nos provérbios romenos do século XVIII

Autor(es): Laura Badescu

Enquadramento Institucional: Centro de Estudos Medievais, Faculdade de Letras,

Universidade de Pitesti, Pitesti, Romenia

Contacto: laura.e.badescu@gmail.com

Fonte: Medievalista [Em linha]. №13, (Janeiro - Junho 2013). Dir. José Mattoso. Lisboa:

IEM.

Disponível em: http://www2.fcsh.unl.pt/iem/medievalista/

ISSN: $1646-740 \mathrm{X}$

\section{Resumo}

Propõe-se uma análise do conceito de "politheia" relacionando-o com um corpus paremiológico romeno utilizado no século XVIII. Para tal, serão descritos três contextos (genético, genérico e funcional) que causaram mutações semânticas nas estruturas paremiológicas. Pretende-se explicar estas mutações destacando as conexões entre enunciados sentenciais e o quado político, social e cultural.

Palavras-chave: Politheia; Paremiológia; cultura romena, século XVIII, politheia. 


\section{Abstract}

The paper proposes an analysis of the concept "politheia" in relation with Romanian paremiologic corpus used in the eighteenth century. In this framework, it was described three contexts (genetic, generic and functional) that caused mutations in the semantic of paremiologic structures. The intention is to explain these changes by highlighting the connections between sentential statementsand the political, social and cultural zeitgeist.

Keywords: Politheia; Paremiology; Romanian culture, Eighteenth century, Politheia.

\section{Política e politheia nos provérbios romenos do século XVIII}

\section{Laura Badescu}

\section{Preâmbulo}

O presente trabalho ${ }^{1}$ terá como corpus duas categorias de textos; por um lado, antologias de literatura sapiencial: provérbios, parábolas, construções paremiológicas difundidas no séc. XVIII romeno e, por outro lado, as obras redigidas por (ou a conselho de) personalidades com um papel relevante na vida política e social dos países romenos.

\footnotetext{
${ }^{1}$ Este trabalho foi realizado no âmbito do projecto "Valorização de identidades culturais no processo de globalização", financiado pela União Europeia e o Governo da Roménia no âmbito do Programa Operacional do Fundo Social Europeu de Desenvolvimento de Recursos Humanos 2007-2013, com a referência POSDRU/89/1.5/S / 59758.
} 
No caso da primeira categoria de textos, referir-nos-emos às antologias com mais variantes e edições publicadas nos países romenos: Floarea darurilor (A flor das virtudes) e Pildele filosofesti (As parábolas filosóficas) (I), na segunda categoria o Manual do Rei Ioan Nicolae Alexandru Mavrocordat (II), Conselhos do Rei Nicolae por seu filho Rei Constantin dados em 1726 (III).

Com base na difusão atestada destas antologias, não consideramos um inconveniente o facto de se tratar tanto de traduções como de obras originais, produzidas no espaço romeno, porque estas obras traduzidas sofreram evidentes transformações de uma edição a outra e de um manuscrito a outro. Este é um forte argumento para a sua refundição e adaptação ao espaço cultural romeno.

Mencionemos que a variedade temática, estilística e funcional destas obras que retomaram na sua estrutura construções sentenciosas é surpreendente no âmbito da cultura romena. Deste modo, as construções sentenciosas aparecem no séc. XVIII na literatura histórica (crónicas oficiais), literatura beletrística (livros populares: romances, lendas, contos, fábulas), literatura administrativa (temos em conta o grande diplomatarium romeno em que os provérbios se tornam funcionais em contexto argumentativo, demonstrativo, conclusivo, etc.).

Para ilustrar da forma mais eloquente possível os modos de assimilação da literatura paremiológica na cultura romena, considerámos o primeiro romance romeno como corpus de textos paremiológicos da presente análise.

Esta opção deve-se ao facto de Istoria ieroglifica (a História hieroglífica) do príncipe Dimitrie Cantemir ter sido redigida sob o auspício da "verdade histórica", assimilando os "topoi” populares e clássicos, técnicas retóricas e normas epistolográficas, etc., ilustrando o esforço de afiliação cultural dos romenos aos movimentos europeus contemporâneos. É interessante notar a este respeito as palavras do príncipe Cantemir inseridas no prefácio do seu romance alegórico indicando a presença de 760 provérbios e cuja função é a de embelezar a sua obra.

Simultaneamente, com vista a uma mais exacta descrição do contexto genético, consideraremos as crónicas históricas e a literatura jurídica do séc. XVIII. 


\section{O contexto genético. Breve histórico do séc. XVIII fanariota}

O que determinou que na literatura romena do séc. XVIII aparecessem como dominantes as expressões paremiológicas centradas principalmente no vício e nas suas consequências na vida política, é determinado por um complexo de factos históricos sem precedente nos Países Romenos.

O século XVIII ficou na nossa história como o século dos desastres naturais em que as epidemias de peste devastavam as tropas sobreviventes que transformaram o território romeno em teatro de operações.

No plano político, a instabilidade maior teve como causa a instauração do regime fanariota2: "Uma particularidade da época passa pela transferência por curtos intervalos de tempo dos príncipes fanariotas de um país para outro, procedimento que sobretudo no plano económico-fiscal teve graves consequências. (...) As substituições dos senhores fanariotas, às vezes por curto espaço de tempo (estando eles próprios preocupados com a ocupação das vagas), cerca de 37-38 vezes no País Romeno e Moldova num intervalo de 110 anos deram origem ao sistema de leiloar o trono, uma política baseada na corrupção e na venalidade, mantida por credores dos senhores e alguns dos altos funcionários da Porta (Corte Otomana), que os sustentam”3.

Este é um século que se confronta com grandes mutações sociais, com défice demográfico, com tributação excessiva e arbitrária, escassa monetização da economia,

\footnotetext{
${ }^{2}$ Ver: CERNOVODEANU Paul, EDROIU, Nicolae - Istoria Românilor. Românii între Europa clasică si Europa luminilor, Vol. VI. Bucuresti: Editura Enciclopedică, 2002, pp.32-33: "No que diz respeito ao contacto com o regime fanariota, é sabido que se estabeleceu a partir da segunda metade do séc. XVII, quando a Porta tentou assegurar uma maior submissão dos romenos, (...) para impedir a conquista dos dois estados danubianos por parte das grandes forças cristãs que se afirmaram no sudeste europeu, Áustria dos habsburgos e Rússia czarista. Os senhores fanariotas continuavam portanto no séc. XVIII uma fórmula já experimentada, provando maior obediência perante Istambul, de que dependiam directamente. Estes príncipes estrangeiros, apesar de limitados pela dominação otomana, quiseram porém a legitimação das suas pretensões como suseranos dando resplendor e fausto à Corte senhorial, respeitando as tradições da Ortodoxia, que podia ligá-los ao passado do país. (...) No intervalo de tempo entre 1711 e 1821 , era a Porta que dava a senhoria aos representantes de 11 famílias da nobreza de Fanar ou greco-romena fanariotizada, ou seja: Callimachi (Calmasul), Caragea, Ghica, Hangerli, Ipsilanti, Mavrocordat, Mavrogheni, Moruzi, Racovita, Giani-Ruset e Sutu.”. (trad. n.).

${ }^{3}$ CERNOVODEANU Paul, EDROIU, Nicolae, Idem, p.34.
} 
com o monopólio otomano sobre o comércio, com a proliferação da criminalidade por pilhagem e roubo ${ }^{4}$, etc. Contudo, para os países romenos, este século trouxe prosperidade cultural através de algumas ilustres personalidades que apoiaram sobretudo o ensino e a justiça, pela adaptação de programas escolares seguindo o modelo das Luzes europeias, respectivamente através da edição de códices de leis. Enumeramos apenas os dois Mavrocordat, Nicolae e o seu filho Constantin, Grigore II Ghica, Alexandru Nicolae Caragea, Scarlat Callimachi etc.

Concluindo, o século fanariota aparece como um período de fortes contrastes entre a indigência e a opulência, entre obscurantismo e resplendor intelectual. Os historiadores consideram que foi neste século que surgiram duas máxima que reflectem o estado das classes sociais inferiores: assim, "A morte é o repouso do pobre", e outra, com uma visão sobre a época, lembra que "os amigos desta época são os urdidores dos nossos actos", alusão ao aparelho opressivo do regime fanariota, devotado à Corte Otomana"

\section{Contexto génerico. A circulação das antologias de sentenças, máximas e parábolas na cultura romena}

A afirmação "as colectâneas de máximas e parábolas foram escritas nos países romenos desde os primórdios da utilização da escrita" (trad. n.) ${ }^{6}$ constitui para a história da cultura e da literatura romena uma tese baseada na multiplicidade e variedade dos manuscritos conservados ou atestados (ainda) do séc. XIV ${ }^{7}$.

Transcrevemos aqui os títulos de algumas das mais representativas obras em circulação até à segunda metade do séc. XIX: Dioptra séc. XVI, Albina (Abelha) séc. XVI, Floarea darurilor (A flor das virtudes) séc. XVI, Cugetarile lui Oxenstiern (Os

\footnotetext{
${ }^{4}$ Ver LIVADĂ-CADESCHI, Ligia - De la milă la filantropie. Instituţii de asistare a săracilor din Țara Românească şi Moldova în secolul al XVIII-lea. Bucuresti: Editura Nemira, 2001, pp. 41-69.

${ }^{5}$ CERNOVODEANU, Paul, EDROIU, Nicolae, Idem, p.730.

${ }^{6}$ DUŢU, Alexandru - Cărţile de inţelepciune în cultura română. Bucuresti: Editura Academiei Republicii Socialiste România, 1972, p. 15.

${ }^{7}$ Para a variedade e quantidade das colecções da cultura romena desde o séc. XIV, ver Alexandru Duţu, Cărţile de înţelepciune în cultura română , Bucuresti, Editura Academiei Republicii Socialiste România, 1972, p. 15 ş.u. Veja ms. slav. 72, Biblioteca da Academia Romena - BAR, ms. slav. 68 BAR, ms. slav 130 BAR, ms slav 157 BAR, ms. gr. 140 BAR etc.
} 
pensamentos de Oxenstiern) séc. XVIII, Carare pe scurt (Carreiro breve), Adunare de pilde (Florilégio de parábolas) (Dinicu Golescu, 1826), Culegere de întelepciune (Colecção de sabedoria) (Nicolae Darvar, 1827), Moralnice sentinţe (Sentenças morais) (I. Teodorovici-Nica, 1813), Pilde, povatuiri, cuvinte adevarate si povesti (Parábolas, conselhos, verdades e contos) (Iordache Golescu), etc.

Além destas colecções em língua romena, circulavam simultaneamente nos países romenos as antologias em eslavo antigo ou grego ${ }^{8}$. Esta difusão revela que este género de literatura correspondia a um certo gosto, desenvolvido preferencialmente com base em razões funcionais, porque estes eram dos poucos textos laicos que impunham normas de conduta, sistemas de avaliação moral sem transgredir a literatura religiosa.

É nesta perspectiva que se pode ler o esforço de príncipes e prelados romenos em compor antologias e colecções, as quais na sua maioria permaneceram desconhecidas do grande público. Citemos aqui a colecção de provérbios de Alexandru Mavrocordat, bem como a de Nicolae Mavrocordat que totalizam 866 pensamentos e máximas, ou a de Antim Ivireanul (1715) .

As opiniões dos historiadores romenos divergem quanto a uma certa preferência por uma colecção. Desta forma, entre as leituras preferidas do leitor do século XVIII encontrar-se-ão tanto Floarea darurilor (A flor das virtudes) ${ }^{10}$, como Pildele filosofesti (As parábolas filosofais) ${ }^{11}$ ou Cugetari privitoare la diferite subiecte, însotite de

\footnotetext{
${ }^{8}$ Ver, por exemplo, CAMARIANO-CIORAN, Ariadna - Academiile domnesti din Bucuresti si Iasi, p. 126: "Julga-se que Ioan Commen traduziu em 1697 a conselho de Brâncoveanu em neo-grego Maxime de regi si generali (Máximas dos reis e generais), respectivamente, Maxime de filozofi si retori (Máximas dos filósofos e reitores) (Ms. gr. 1044 BAR)" s.a. (trad. n.).

${ }^{9}$ Para Alexandru Mavrocordat ver DUȚU, Alexandru - Cartile de intelepciune in literatura romana, pp. 83, 84; para Nicolae Mavrocordat ver a colecção de 866 pensamentos e máximas publicadas em Documente privitoare la istoria românilor recolhidas por Euxodiu de Hurmuzaki, trad. por G. Murnu e C. Litzica, vol. XIII, Bucuresti: Institulul de Arte Grafice Carol Gobl, 1940-1914, pp. 417-457, 415-416; Para a antologia de Antim Ivireanul ver C. Erbiceanu em BOR. 1890, pp. 333-355.

${ }^{10}$ OLTEANU, Pandele - Floarea darurilor sau Fiore di virtu, Studiu, ediţie critică pe versiuni, după manuscrise, traducere şi glosar în context comparat, Timişoara: Editura Mitropoliei, 1992, ver p. 26 ş.u. Ao longo do tempo, Floarea darurilor conserva-se em mais de 40 de manuscritos e cinco edições espalhadas em todo o território romeno.

${ }^{11}$ Ver DUȚU, Alexandru - Coordonate ale culturii româneşti în secolul XVIII..., pp. $49-53$ passim: "trabalho traduzido em italiano por Del Chiaro, para ser, depois, redigido em grego pelo pregador da Corte, Ioan Avramios, e, finalmente em romeno por Antim Ivireanul, é Les bons mots et les Maximes des Orientaux. Traduction de leurs ouvrages en arabe, en persan et en turc. Avec des remarques. Par Mons. A. Galland. A Paris, 1694.” (...) Em 1783, o livro é publicado de novo em Râmnic, sob a
} 
reflectiuni morale (Pensées diverses sur divers sujets avec des refléxions morales) ${ }^{12}$ do conde d'Oxenstiern.

Uma importante característica das variantes destes livros é representada pela sua adaptabilidade às normas e necessidades do período e da zona em que foram copiadas ou editadas. Ao analisar as variantes manuscritas das Pildele filosofesti (As parábolas filosofais), o Professor Al. Dutu observa uma mutação permanente no tocante à selecção das máximas. Assim, no fim do séc. XVIII, esta mudança é visível no "Ms. 116 e Ms. 3275 colecções de sentenças irónicas, um pouco misóginas, pertencendo a um certo tipo de humor que se desenvolve naquela época. Por outro lado, no Ms. 3093 as máximas aparecem junto às normas jurídicas, extraídas das leis de prestígio de sudeste europeu"13 (trad.n.).

A modificação da temática preponderante nestas antologias torna-se mais eloquente através da comparação da atitude perante a política e o uso ordinário nos textos anteriores ao séc. XVIII com colecções deste mesmo século ${ }^{14}$. A crítica é concordante

responsabilidade de Grigore Râmniceanu (...); no mesmo ano, para dar resposta aos leitores de Transilvânia, o livro sai numa nova tiragem em Sibiu (...). Na mesma cidade, em 1795, vê a luz uma edição parecida com o índice do livro publicado por Antim (...). As duas edições, de 1713 e 1783, foram recopiadas pelos mestres de todos os três países romenos e a difusão dos manuscritos (se nos referirmos apenas às colecções da Biblioteca da Academia de Bucareste) revela o sucesso que teve o livro durante algumas décadas. Mas as máximas foram ainda republicadas em Octoihul mic, aparecido em Iasi, em 1786, sob a responsabilidade de Leon Gheuca (...)". "Dos 25 manuscritos de Pildele filosofesti: 10 são redigidas na Valachia, 8 em Moldova e 7 na Transilvânia; 3 foram copiadas na primeira metade do séc. XVIII, 17 ao findar do século, e 5 nas primeiras décadas do século seguinte.”

${ }^{12}$ Ver ELIADE, Pompiliu - Influenţa franceză asupra spiritului public în România. Originile. Bucuresti: Editura Univers, 1982, pp. 270-271: "De todos estes livros, o que despertou maior interesse e foi considerado mais digno de ser traduzido na língua do país foi um opuscus pouco conhecido, escrito em francês por um sueco Cugetari privitoare la diferite subiecte, insotite de reflectiuni morale (Pensées diverses sur divers sujets avec des réflexions morales), do conde d'Oxenstierna (Gabriel Thurelon, 16411707), famoso homem de estado. O livro contém reflexões sobre a tristeza, a solidão, a ira, sobre a ciência e a religião, sobre Caesar e Pompei. A seguir a Télémaque, é a obra francesa que teve maior sucesso nos Principados. Foram encontradas várias cópias manuscritas da tradução, todas sem o nome do tradutor: uma de 1781, outra de 1782, escrita pela mão de um arquidiácono Isaac, a terceira sem datação, a quarta sem datação e inacabada."

${ }^{13}$ DUȚU, Alexandru - Coordonate ale culturii româneşti în secolul XVIII..., p. 53

14 É importante para a nossa análise a afirmação de OLTEANU, Panadele - op. cit., p.17: "Os pensamentos de Floarea darurilor enriqueceram a história da obra tornando-a actual ainda hoje em dia. Foram copiados e separados, espalhando-se em manuscritos. Pela selecção, foram utilizadas largamente nos discursos, nos manuais escolares. Foram reunidas em função de temas em osmose de pensamentos e máximas de outras colecções, como as orientais recolhidas por A. Gauanad (Paris, 1694) e traduzidas em romeno como Pilde filosofesti em a. 1713. Como monumenta humana os pensamentos de Floarea darurilor encontram-se nas colecções paremiológicas de alguns grandes humanistas, filósofos e pedagogos como Erasmus de Rotterdam (...), I. A. Comenius (...)". 
quanto à assimilação das antigas colecções de provérbios em outras novas através da obediência ao espírito da época imposto pelas modificações que uma comunidade atravessa no plano social e político. Ao percorrer as sucessivas edições das Pildele filosofice (As parábolas filosóficas), verificar-se-á que é possível relacionar as máximas adicionadas na edição de 1713 com a reforma do sistema jurídico romeno, particularmente intensa no tempo de Callimachi e Ipsilanti: “Onde há muitas leis, há muitas injustiças." (I, p. 114) ou "O peso maior que a terra carrega é o de uma pessoa impune." (I, p. 115). Ao mesmo tempo, a edição de 1783 foi amplificada com máximas que promoveram a iluminação por meio da cultura "Miserável é a pátria que tem muitos ignorantes, porque o rico mesmo culpado tem mais louvores e mais honras do que os eruditos" (I, p. 115).

Porém, estas mutações são ainda mais visíveis na literatura histórica, sobretudo através da marca paremiológica. Neste sentido, a síntese de Nicolae Iorga relativa às construções paremiológicas relacionadas com as normas habituais romenas continua eloquente: "O conceito político superior implica a noção de ordem monárquica tradicional, necessária. O senhor é necessário, e não é bom ser trocado: “A mudança dos senhores é a alegria dos néscios." Dele vem e parte tudo. Constantin-Voda Cantemir sabia bem que "O senhor faz o povo e o senhor o destrói." A transformação das pessoas em dignidades é uma fatalidade que é necessário aceitar: "O pão de Voda come-se à vez." As usurpações de qualquer tipo não são bem vistas: "O cigano, quando se torna senhor, logo enforca o seu pai." Ou: "Ora trajo de honra, ora corda no pescoço." Ou mesmo: "Adormeces camponês e acordas grande senhor". Em todo o caso, a dignidade não se herda: "De que vale o teu pai ter sido senhor, se tu não és humano.” Ou: “À noite porqueiro, de manhã dignitário." É bom: "Proteger-te do velho mendigo e do novo alto funcionário.” Do cobiçoso de glória diz-se: "Far-me-ia turco para ser Paxá.” Mas não faz mal saber que "Quem espera por cornos (altos títulos) perde as orelhas." Ou: "Dizse que as nozes dizem que do seu fruto nascem os amendoins." Mas: "Quem pode, ossos rói." Existe também uma espécie de receio da glória rápida, como na expressão rítmica ${ }^{15}$ em romeno "Quanto mais alto se sobe maior é queda."

\footnotetext{
${ }^{15}$ Pomul mare cade tare.
} 


\section{Política e "polithea" - ou confluências entre contexto genético e genérico e aplicabilidades em contexto funcional}

O conceito fundamental do humanismo barroco, tirado dos inventários do Renascimento, de "interesse colectivo", provém na cultura romena da filiação bizantina do significado de "polithea": conjunto de normas civilizacionais com vista à prestação útil ao serviço de uma certa comunidade ${ }^{17}$. Na cultura romena, "o interesse colectivo" constituiu ao mesmo tempo uma finalidade ética revelada à comunidade, uma chave de interpretação, um objectivo educacional proposto aos semelhantes e um critério de avaliação" $^{\text {"18. }}$.

Para ilustrar estas acepções de "polithea", seguiremos a ordem temática dos enunciados sentenciosos difundidos no séc. XVIII romeno, na forma em que estes ocorrem nas antologias utilizadas ${ }^{19}$, bem como na História hieroglífica do príncipe Cantemir.

Começamos este percurso com as palavras do príncipe Cantemir ${ }^{20}$, respectivamente de Mavrocordat: "Entre mortais, não há mais honesto e mais verdadeiro elogio, do que aquele que se consegue com a contribuição Pública" (IV, Nr 613) e "É mais útil e mais louvado morrer em honra pela liberdade e herança, do que viver muitos séculos sem honra” (IV, Nr 370); “Os que não poupam a sua própria vida para o senhor, realizam um valioso serviço e são na verdade livres" (II. p. 423).

Observemos, em primeiro lugar, o contexto genético em que são promovidas as sentenças consideradas "polithea". Assim, nas antologias, a época está marcada pelo signo da alteração humana ("Não há justiça no dizer que o século se alterou porque não

${ }^{16}$ IORGA, Nicolae - Istoria literaturii românesti, vol I, segunda edição. Bucuresti: Editura Librăriei Pavel Suru, 1925.

17 MAZILU, Dan Horia - Recitind literatura română veche, vol. I. Bucuresti: Editura Universităţii Bucuresti, 1994, pp. 316-323.

${ }^{18}$ MAZILU, Dan Horia, Idem, p. 317.

${ }^{19}$ Pilde filosofesti (I), Manual in care se cuprind pareri si cugetari cu privire la moravuri si purtări, scrise de prea cucernicul, prea înălţatul şi prea învăţatul domn şi stăpânitor al Moldovei întregi şi al Ungro-Vlahiei, Kir Ioan Nicolae Alexandru Vodă Mavrocordat, Traducere de G. Murnu (II), Sfaturi ale răposatului domn Nicolae Vodă către fiul său Constantin vodă date în anul 1726 (III).

${ }^{20}$ Utilizamos como livro IV: CANTEMIR, Dimitrie - Sentenţii, Maxime şi cugetări din Istoria Ieroglifică. Bucuresti: Editura Gramar, 2003. 
foi o século que se alterou, mas as pessoas deste século" (I, 247.7, p. 82)), do engano e do desrespeito pelos valores ("Não fiques admirado se vires as pessoas mais dignas infortunadas e difamadas, nem se vires as altas funções nas mãos dos indignos; abre os olhos e procura ver como as estrelas, sendo inumeráveis, nunca perdem a luz e como a terra roda só para nos mostrar às vezes a ausência da lua e outras vezes a ausência do sol.” (I, p.112), da desigualdade social (I, p.87) "O diabo não tem força sobre os bons, nem o senhor sobre os pobres") etc.

Parece não fazer sentido endireitar-se porque " $\mathrm{O}$ mundo perdeu a cabeça e oferece os que lhe são semelhantes; mas ai deles se o mundo alguma vez despertar.” (I, p.110).

No contexto funcional descrito pela Istoria ieroglifica (a História hieroglífica), a época aparece caracterizada pelos mesmos atributos porque "Como nos tempos antigos, os caprichos dos senhores eram a lei dos súbditos" (IV, Nr. 42), e a decadência da sociedade surge sobretudo do interior, com base no princípio "as grandes senhorias são derrubadas do interior": "Não traz tanto dano ao Público, a reunião dos inimigos do exterior, como aos cidadãos do interior, os pensamentos" (IV, Nr 193) "E tanto como um membro sofre de uma incurável doença/ pouco a pouco provoca ao corpo inteiro a morte,/ Assim em toda a Pública, correndo um mau pensamento e despeito sobre os outros,/ derruba sempre a monarquia" (IV, $\mathrm{Nr} 81$ ).

\subsection{O sistema jurídico}

O critério de avaliação recomendado através destes enunciados sujeita-se aos dois sistemas do direito romeno praticado até à segunda metade do século XIX: o de direito costumeiro (consuetudinário, usual), e o de um direito escrito ${ }^{21}$.

\footnotetext{
${ }^{21}$ Inicialmente houve influências bizantina e eslava sobre o direito romeno, depois, no séc. XVII e XVIII turca e, ulteriormente, austríaca e francesa. Ver Indreptarea legii, Manual juridic (1766) alcatuit de Mihail Fotino din Hios, Legea din 1765, Nomocanonul lui Gheorghe din Trapezunt (1730), Pravilniceasca Condică (1780), Alexandru Ipsilante, Pandectele lui Toma Carra (1806), Codicele Kalimah (1816), Legiuirea lui Caragea (1818).
} 
A coexistência dos dois sistemas atesta-se em todos os códigos jurídicos romenos (“Onde não há lei escrita tem de se respeitar o hábito local”,22 e "o tribunal tem de julgar segundo a lei e os costumes da terra"23). Com base nas múltiplas analogias entre os códigos normativos e as parábolas das colecções, assinalamos alguns exemplos que revelam temas como o da cumplicidade, do ultraje ou do castigo: "Semear flores na escória é fazer bem ao impune e ao velhaco" (I, Nr 6); "O fardo maior que a terra carrega é a pessoa impune" ${ }^{24}$; "O sinal do julgamento iníquo é quando o julgado profere injúrias contra o seu oponente" ${ }^{25}$; "Quem perdoa aos maus faz injustiça aos bons" (I, p.86).

O castigo imediato e a justiça directa são igualmente clamadas historicamente no romance alegórico analisado, através de: "Tal como na bainha curvada, a espada direita,/ Nem na bainha justa, espada curvada;/ Entrar não pode;/ Assim, onde é anulada ou a mutação da benevolência,/ Toda a esperança da direita justiça é posta fora" (IV, 21); "O sinal do verdadeiro monarca é este: nem com a agulha picar, nem com os dentes morder, nem com as unhas romper, mas graça aos pecadores, castigo aos maus, piedade aos submissos, justiça aos estranhos e continuação nas fronteiras da sua monarquia mostrar" (IV, Nr 367). Mavrocordat mostra mais indulgência: "O juízo tem de ouvir com muita (prolongada) paciência e seriedade aqueles que se queixam e aqueles que se defendem; porque esta é também uma grande qualidade da justiça. Ao contrário, quem neste intervalo faz eco e não pára de falar, é um sino que tine. Mas é possível que este trave a torrente e o fluxo das palavras supérfluas das partes e das diversas pessoas, com habilidade examine a medula da justiça, porque às vezes esta se esconde atrás da multidão das palavras; porque é preciso que os juízos segundo o exemplo de Deus humilhem a arrogância e realcem a humildade derrubada" (II, 857, p. 456).

Nas antologias, o panorama em que a justiça ideal se exercita pressupõe a presença dos líderes amadores da justiça (“Os imperadores são para proteger as leis, e as leis bem protegidas realçam glória dos impérios” (I, p. 104)), os que sabem que "A glória dos

\footnotetext{
${ }^{22}$ Ver Îndreptarea legii, cap. "Despre obiceiurile nescrise ale marii biserici." Şi obiceiul statelor se cheamă datină; pp. 661 - 662.

${ }^{23}$ Pravilniceasca Condică (1780), apud. V. Ursăcescu, BOR, 506, ver Codicele Callimachi onde se diz que contém "mais leis... em conjunto com os costumes do país" V. Ursăcescu, BOR, 506.

${ }^{24}$ Ver Îndreptarea legii, cap. 343 ş.a.

${ }^{25}$ Idem, p.167-168.
} 
imperadores é visível quando fazem justiça” (I, p. 100), e "Um senhor justo é ícone e semelhante de Deus na terra" (p. 98), e "Os submissos vêem no comportamento do senhor um modelo" (II, 138, p. 422).

Do mesmo modo, na História hieroglífica, "O Povo prospera e desenvolve-se quando os senhores têm piedade e repreendem com justiça e os súbditos são obedientes e servem com amor" (IV, Nr. 462).

A justiça directa e a governação iníqua são sancionadas nas colecções porque "A vida dos tiranos não é longa" (I, p. 84), e "Um senhor que não tem justiça é semelhante ao rio sem água" (I, p. 91). O conjunto censurado em que se indica os vícios associados à tirania: "O imperador injusto não tenha esperança que o seu império dure, nem o soberbo que seja louvado, nem o pagão que tenha muitos amigos, nem o avaro que seja considerado benfeitor e boa pessoa, nem o vencedor iníquo que seja chamado justo e sincero" (I, p.92).

Ainda mais pessimista é o exemplo do príncipe Cantemir que, com base na sua experiência política assumida, observa que "Os tiranos quando falham em fazer mal, mobilizar-se-ão para uma segunda tentativa sucedida" (IV, Nr. 636).

Na edição das parábolas de 1713 foi incluída a máxima "Onde há muitas leis, há muita injustiça" (p.114) que relacionamos com a justiça corrupta e os consequentes abusos. Deste modo, nas antologias II, III observamos que o receio dos dois príncipes se baseia na perversão das leis: “A modificação das leis existentes não é permitida aos juízes de modo nenhum, mas apenas a sua interpretação fundamentada com justiça, repartindo a fraqueza humana com a devida piedade através do desenvolvimento das partes mais duvidosas no sentido mais humano" (II, 850, p. 456) e "A perversão das leis ao benefício dos seus semelhantes é algo repugnante. Portanto, não é mester que as leis referentes aos castigos e sobretudo as capitais, sejam desviadas e pervertidas, aplicando a crueldade destas às injustiças comuns; e o crime sendo desde o início conhecido pelas leis, não é mester que uma curiosidade inoportuna admita a maldade impune" (II, 841, p. 455). Por isso: "São saudadas e seguras apenas as leis que, dada a sua transparência e claridade, não precisam da interpretação dos juízes" (II, 840, p. 454 e 851) "A 
corrupção é o veneno da justiça; apenas aqueles que não untam as mãos são verdadeiros juízes íntegros na forma e no acto” (p. 456).

\subsection{Organizações sociais: funções - líderes e liderados. Códigos normativos}

A colecção das parábolas enuncia abundantemente as regras que constituem um código normativo da conduta que é recomendável ser respeitada tanto pelos líderes como pelos liderados. A dedicação aparece como fundamental, porque "Não abandone multidão o seu imperador, nem lhe seja desobediente sem grande derramamento de sangue" (p.84).

Maioritariamente, as máximas aqui inseridas provêm da Floarea darurilor. As estruturas binárias e os gnomas contendo cifras utilizadas indicam este facto.

Nas colecções de parábolas aparece o líder hábil e forte, ideal ao serviço do povo: "Sacia-se o povo quando consegue um senhor que não adormece, porque o soberano que não cansa traz repouso aos outros" (I, p.94).

É recomendável a prudência e a diplomacia: "Não te metas sozinho numa coisa que diz respeito a todos, porque se não sai bem, és o culpado, mas se sai bem os outros serão elogiados" (fila 6), "É mester que o sensato se retire a tempo de uma confusão política, ou seja, quando percebe que é uma carga inútil, e não é capaz de se impor à comunidade; porque, assim como alguém disse, não deves emprestar a quem não pode devolver" (II, 26, p. 418), bem como "Foge da amizade dos imperadores, assim como o fogo da madeira seca" (I, p. 96) e "Bate a cabeça da serpente com a mão do teu inimigo, porque das duas uma: ou a serpente morrerá e vencerá o teu inimigo, ou vencendo a serpente, o teu inimigo morrerá"” (I, p. 87). Cantemir apresenta a mesma prudência como norma, porque: "É melhor afastar um pérfido do que trazer dez sábios." (IV, Nr. 29), bem como "Descobre os defeitos dos altos funcionários e protege-te destes, mas negligencia-os para teres tranquilidade, e os dos teus, não os toleres" (III, p. 416).

Entre os gnomas representativos para o nosso tema que contêm as cifras 3 e 5 estão: "Quem verdadeiramente merece o nome de humano conhece-se por cinco sinais: em primeiro lugar, não muda independentemente do que lhe acontecer; em segundo lugar, 
quando é louvado é humilde; em terceiro lugar, não foge quando é preciso mostrar a sua valentia; em quarto lugar, não tem outro pensamento do que a sua glória e honra. E em quinto lugar, se não é instruído, pelo menos ama os sábios e os instruídos” (V, 7 v, 8 r) ou "Quem serve os imperadores e os altos funcionários deve seguir cinco regras para não dar ocasião ao seu inimigo de lhe fazer mal: em primeiro lugar, não é mester mentir ao seu senhor; em segundo lugar, nunca dizer mal de ninguém perante o senhor; em terceiro lugar, nunca se opor a nada; em quarto lugar, sempre servir o seu senhor; e em quinto lugar, nunca revelar o segredo partilhado" (V, $70 \mathrm{v}, 71)$; bem como, "Os imperadores gostam de três coisas: os artifícios bonitos, as riquezas e os elogios" (I, p. 107); Três coisas contentam o império de um imperador: a disponibilidade de se aproximar dos seus súbditos, a justiça e a piedade" (I, p. 107) ou "Na política reina ou a lei ou o poder. Porque às vezes o poder substitui a lei e algumas leis contêm mais poder do que justiça. A injustiça tem três fontes: o poder ilimitado, o engano escondido sob a forma da lei, a interdição e a severidade da lei” (II, 834, p. 454).

A ausência dos gnomas que contêm cifras da obra de Cantemir, bem como a sua escassa utilização nas colectâneas dos dois Mavrocordat podem indicar a desatenção face a este modelo imposto pelos livros populares com uma finalidade mnemotécnica.

A ordem hierárquica que deve seguir um alto funcionário, bem como a sua motivação na ascensão são, também, descritas através dos seguintes gnomas: "Quem se quer formar na corte do senhor, é mester respeitar três coisas (regras): em primeiro lugar, endireitar com bondade e ternura a sua ira (a ira do senhor); em segundo lugar, não permitir que seja dominado pela avidez; em terceiro lugar, ser justo e direito na sua fazenda; em quarto lugar, não permitir o pecado da arrogância; em quinto lugar, não se perturbar ao ser confrontado com a maior contradição" (I, p. 95-96); mas "É mester que o sensato da corte senhorial, deve esforçar-se, se for possível, a subir na hierarquia, para poder fazer bem aos seus amigos e impedir os inimigos nas suas fazendas" (I, p. 95). Assumir a verdade é a atitude que se recomenda ao conselheiro: "Só quem não tem medo de perder a sua vida, nem espera recompensa, deve dar conselhos ao imperador" (I, p. 90).

É mais fácil para um miserável subir na hierarquia e isso é em detrimento de toda a gente: "Infelizes são tanto os imperadores como os súbditos quando são difamados os 
dignos e os miseráveis ocupam as funções mais altas" (I, p. 97). "Os medíocres perseguem a glória e depois dizem que esta os persegue.” (II, 742, p. 447) e por outro lado, "Muitos se acham hábeis para as altas funções e quando as conquistam provam o contrário" (II, 379, p. 430).

Contudo, nas colectâneas de máximas, a propaganda da ideia que as altas posições se conquistam através dos méritos pessoais e não por meios injustos ou pela "boa família" reflecte uma forte influência do humanismo europeu: "A glória conquistada pela benevolência é maior do que a herdada" (I, p. 84); "Para conquistar uma alta função não é necessária a boa família, nem a valentia, mas o espírito e a sabedoria, porque pela inteligência se consegue tudo" (I, p. 95) e "Às vezes o servidor é mais perspicaz do que o boiardo" (I, p. 92). Esta particularidade não se encontra na obra do príncipe, nem nas duas colecções dos Mavrocordat. O conselho quanto ao conhecimento do próprio valor aparece constantemente formulado porque "Os néscios rapidamente sobem (na hierarquia), mas os sábios não.” (I, p. 84).

\subsection{Virtudes necessárias para o interesse público: Sapientia}

Entre as virtudes mais apreciadas pela comunidade, a mais invocada é, então, a sabedoria porque: "Para o imperador, mais vale os conselhos dos sábios do que as dádivas para os sábios" (p. 85) e “Os sábios são os verdadeiros boiardos e os verdadeiros senhores de todo o povo e lugar" (p. 101) e "Responder às perguntas pérfidas com uma pergunta justa é uma característica da sabedoria, que tem como mestre a palavra do suserano" (II, 819, p. 452). A má companhia do sábio é constantemente sancionada: "O instruído acompanhado pelos néscios não é honrado" (I, p. 89). Nas máximas amplificadas na colecção de 1783 pode-se observar a ausência da sabedoria explicando a injustiça e os falsos valores: "Miserável é a pátria que tem muitos ignorantes, porque o rico, mesmo culpado, tem mais louvores e mais honras do que os eruditos" (p. 115) e "Os sábios devem vestir-se com a honra mais alta para poder enfrentar os ataques dos néscios" (II, 398, p. 430). 
Na obra do príncipe o topos circunscreve-se da mesma forma (nos mesmos itens). Assim sendo, "O conselho do pobre instruído e sábio nenhum imperador louco consegue entender" (IV, Nr. 110) e "Assim como todos os membros do corpo precisam de uma cabeça, o povo precisa de um espírito justo" (IV, Nr. 360) ou "O modelo de governar o povo é o da construção resistente de uma casa em quatro pilares" (IV, Nr. 241).

A história é assinalada com objectividade e encontra-se nos actos sábios "O historiador verdadeiro e o imperador famoso partilham os louvores. Porque o imperador fez os actos e o historiador faz com que estes sejam eternamente recordados" (IV, Nr. 144). A falsidade é sancionada através de um conjunto de pares sinonímicos eloquentes que representam sentenças famosas: "A história para os néscios é uma invenção; a pérola vale a cevada perante os porcos; o apito do pastor é música refinada; o bom conselho dado a uma má pessoa é um desperdício" (IV, Nr. 227).

\section{Conclusões}

A nossa análise confirma um facto particularmente relevante para o século XVIII relativamente ao modo de utilização da linguagem paremiológica romena, ou seja, a reiteração na literatura de autor de algumas construções sentenciosas consignadas nas colecções.

A afirmação no contexto funcional de algumas construções paremiológicas deve ser percebida no sentido de uma dupla tradição, por um lado a instituída na cultura romena e, por outro, a europeia.

As preocupações de tradução e composição de antologias surgem nos Países Romenos como um recuo do que tinha ocorrido na cultura europeia através das reedições sucessivas das colecções de Erasmus. Simultaneamente, está provado por vários estudos da especialidade, o facto de se ter recorrido constantemente à paremiologia desde as crónicas eslavas antigas até às da Moldavia e de Muntenia, etc. 
$\mathrm{Na}$ maioria dos enunciados sentenciosos circunscritos à "politheia", observa-se uma disposição metaforizante diminuída: quando a relação metafórica se institui, esta decifra-se quer através da analogia com um facto concreto (identificado em contexto genético acima apresentado como sinopse da época), quer através de uma técnica de conexão a uma parábola ou a uma série de parábolas.

Os enunciados das antologias, em todos os topoi analisados, apresentam reflexos contextuais identificados rapidamente pelo locutor através da sua circunscrição genética às mutações políticas, sociais e económicas do séc. XVIII. Esta surge como argumento da ligação instituída entre o contexto genético e funcional da "politheia", pelo menos no caso dos textos aqui analisados.

Os modelos, tanto os das antologias, como os do romance alegórico (e referimo-nos com preponderância à série $\mathrm{O}$ espelho do príncipe), foram absorvidos pelo fundo cultural tornando-se o contexto genético. Isto permitiu ao conceito "politheia" tornar-se e adaptar-se em concordância com os usos e os costumes de uma cultura com grande disponibilidade paremiológica.

Através desta análise demonstrou-se que as estruturas paremiológicas circunscritas ao conceito "politheia" passaram com facilidade para a literatura livresca e que esta migração foi, muito provavelmente, a mais usual.

\section{Bibliografia e Fontes:}

\section{Fontes impressas:}

(IV) CANTEMIR, Dimitrie - Sentenţii, Maxime şi cugetări din Istoria Ieroglifică. Bucuresti: Editura Gramar, 2003. ISBN 973-591-417-4

(I) DUȚU, Alexandru - Coordonate ale culturii româneşti în secolul XVIII (17001821). Bucuresti: Editura pentru Literatură, 1968.

(II) MAVROCORDAT, Ioan Nicolae Alexandru - "Manual in care se cuprind pareri si cugetari cu privire la moravuri si purtări, scrise de prea cucernicul, prea înălţatul şi prea 
învăţatul domn şi stăpânitor al Moldovei întregi şi al Ungro-Vlahiei, Kir Ioan Nicolae Alexandru Vodă Mavrocordat", traduzido por G. Murnu, in Documente privitoare la istoria românilor culese de Eudoxiu de Hurmuzaki, vol. XIII, Bucuresti: Institutul de Arte Grafice Carol Gobl, 1940-1914.

(III) MAVROCORDAT, Ioan Nicolae Alexandru - "Sfaturi ale răposatului domn Nicolae Vodă către fiul său Constantin vodă date în anul 1726" in Documente privitoare la istoria românilor culese de Eudoxiu de Hurmuzaki, vol. XIII, Bucuresti: Institutul de Arte Grafice Carol Gobl, 1940-1914.

(V) Pilde filozofeşti depe limba grecească tălmăcite rumâneaşte carele cu cucerie sau închinat, prea Luminatului oblăduitoriu Țării Rumâneşti. Ioann Constandin Basarab Voevod. Fiind Mitropolit Kir Antim, Ivireanul. De Kir Manul al lui Apostoli cu a căruea cheltuială acum întâi sau tipărit în Târgovişste la 1713. Edição do Antim Ivireanul, 1713.

\section{Bibliografia:}

CAMARIANO-CIORAN, Ariadna, Academiile domnesti din Bucureşti si Iasi. Bucureşti: Editura Academiei RSR, 1971.

CERNOVODEANU, Paul, EDROIU, Nicolae coordenação - Istoria Românilor. Românii între Europa clasică si Europa luminilor. Vol. VI. Bucuresti: Editura Enciclopedică, 2002. ISBN 973-45-0248-2

DUŢU, Alexandru - Cărţile de înţelepciune în cultura română. Bucuresti: Editura Academiei Republicii Socialiste România, 1972.

Documente privitoare la istoria românilor, recolhidos por Euxodiu de Hurmuzaki, trad. por G. Murnu e C. Litzica. vol. XIII. Bucuresti: Institulul de Arte Grafice Carol Gobl, 1940-1914.

ELIADE, Pompiliu - Influenţa franceză asupra spiritului public în România. Originile. Bucuresti: Editura Univers, 1982. 
IORGA, N. - Istoria literaturii românesti, vol. I, segunda edição. Bucuresti: Editura Librăriei Pavel Suru, 1925.

Îndreptarea legii, 1652, editor Andrei Rădulescu, Bucuresti: Editura Academiei Republicii Populare Române, 1962.

LIVADĂ-CADESCHI, Ligia - De la milă la filantropie. Instituţii de asistare a săracilor din Ţara Românească şi Moldova în secolul al XVIII-lea. Bucuresti: Editura Nemira, 2001. ISBN 973-569-499-9

MAZILU, Dan Horia - Recitind literatura română veche, vol. I. Bucuresti: Editura Universităţii Bucuresti, 1994. ISBN 973-575-010-4. ISBN 973-575-011-2

OLTEANU, Pandele - Floarea darurilor sau Fiore di virtu, Timişoara: Editura Mitropoliei, 1992.

Data recepção do artigo: 7 Março 2012

Data aceitação do artigo: 24 de Setembro 2012 


\section{COMO CITAR ESTE ARTIGO}

\section{Referência electrónica:}

BADESCU Laura - "Política e politheia nos provérbios romenos do século XVIII". Medievalista [Em linha]. No13, (Janeiro - Junho 2013). [Consultado dd.mm.aaaa]. Disponível em http://www2.fcsh.unl.pt/iem/medievalista/MEDIEVALISTA13/badescu1305.html.

ISSN 1646-740X.

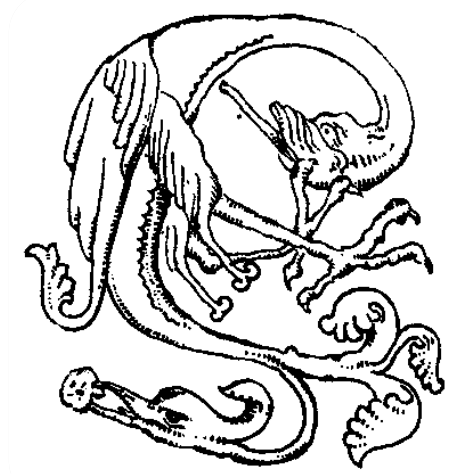

